Article

\title{
Esau is a psychopath? Examining the psychology of the personality of Esau son of Isaac
}

\section{Mladen Cimesa ${ }^{1}$}

University of Bijeljina,Bijeljina, Faculty of Psychology, Pavlovica road nn Dvorovi

\begin{abstract}
In the Old Testament text we find the story of the forefather Isaac and his dizygotic twins Esau and Jacob. Both in the construction of the body and in the psychology of the personality, they were very different, as the Old Testament text testifies. Because dizygotic (fraternal) non-identical twins have a very small chance of inheriting the same chromosome profile, they inherit $15 \%$ to $25 \%$ of the genetic material from each parent, while they share an average of $30 \%$ to $50 \%$ of the genes, so there are clear variations between them. We notice that the basic character trait of Esau is aggression and alpha behavior, while Jacob was a quiet and withdrawn young man in a tent. Later, following the text, we learn that Esau is selling his primacy, which rightfully belongs to him, and according to the words of the apostles, he seeks repentance with tears, but he does not find it. Having an insight into neuroendocrinology and neuroscience itself, we try to hypothetically explain that Esau is, in fact, a psychopathic personality structure and that his behavior and inability to repent are justified by the neurogenesis and synaptogenesis of the profile of people with lower MAOA (monoamine oxidases). behavior. Keywords: Psychopathy, Neuroscience, Old Testament, Esau.
\end{abstract}

\footnotetext{
${ }^{1}$ Corresponding author: mladen_cimesa@hotmail.com
} 


\section{Introduction}

The main focus of this paper consists in the hypothetical explication of neurobiology, which determined the psychology of the personality of Esau, the son of the forefather Isaac. The question of Esau's repentance and its interpretation in the Christian Pauline tradition arises. We must emphasize that the Jewish tradition itself is also not in favor of Esau, especially in the Talmud where there are five terrible sins that Esau committed when he was 15 (Babylonian Talmud, Volume - Bava Basra). The apostle informs us that Esau had no repentance, although he sought it with tears (Bible, Voice of the Church, 2007).

We are interested in the psychopathology of Esau's personality, and whether there is room for a claim about the psychopathic, possibly sociopathic, personality structure of a given subject. The hereditary factor should be taken into account, but also the behavior of the parents, as a basic trigger for the formation of such a phenotype, as well as the environment itself (Hicks et al. 2012). Inadequate behavior of one parent, in this case, the mother, in childhood towards twins is a predictor, that is, it probably influenced Esau's later behavior as a boy without a clear attachment to the mother (Fonagy, Steele, and Steele 1991). The absence of maternal love and the favoring of one child in the relationship - Jacob's mother's favorite - entails the consequences of aggression, but also insecurity (Hofer 2006). Rejection from the mother, potentially due to hairiness and unusual red hair and skin color (gene melanocortin 1-MC1R), certainly contributed to a higher frequency with the father (also due to primacy) and unilateral favoritism according to the patrilineal module. The melanocortin 1 receptor (MC1R) itself is a recessive gene, which is present in the population of people with red hair and is responsible for melanogenesis, but also a strong feeling of physical pain (Lalueza-Fox et al. 2007), and is very little present today, and even at that time it was probably less represented. Only $2 \%$ of the population on planet earth today has red hair (Han et al. 2006). The very need for sensations and exposure to risk, which is evident in Esau (because he goes hunting 
constantly and thus proves masculinity and birthright) is known for dopamine disruption (Zuckerman and Kuhlman 2000), is actually a genetic polymorphism in the dopamine system and we can freely classify (Eisenberg et al. 2007).

Judging by the legend, Esau was open, strong and powerful, so we can conditionally define him as an extrovert, while Jacob was more withdrawn and his mother's favorite, who, by all accounts, had the characteristics of an introvert.

\section{Psychopathy as a possible anamnesis}

According to the Talmudic tradition, Esau is presented as a great sinner, where it is stated that even in adolescence he distinguished himself by misdeeds, more precisely at the age of 15, which could be defined as high-risk behavior because the adolescent's brain is still in the process of development. (up to 25 years of age) (Johnson, Blum, and Giedd 2009) (Babylonian Talmud, Volume -
Bava Basra), while some sources say that Rebecca passed by the idol's house during her pregnancy and felt in her stomach that Esau wanted to go outside, in things force the mother to give birth (Talmudic emphasizing the impurity of Esau), and Jacob did the opposite (Bereshit Rabbah 63: 6), only his name שָָׁ (Shaw) in the Hebrew language means something worthless (Anderson, 2011). Later, according to the Old Testament tradition, from Esau became the Edomites, who in later generations were known as the enemies of Israel (Ackroyd, 1968). The very difference between Esau and Jacob is present from the birth of the former since they are dizygotic fraternal twins who are phenotypically differentiated.

If we take into account the Pauline tradition of interpreting the OT (Old Testament) and the Jewish (Talmudic) we come to the conclusion that they coincide and nuance in many respects, so that Esau speaks of the subject represented in the negative denotation, and is further connoted in the Pauline tradition as a subject who had no repentance, he could not really (sic!) repent. He has evident aggression, dissatisfaction, elements of narcissism (disrespect for parental authority = selling 
birthright) as well as certain characteristics of the criminogenic theory of mind that we find in the Talmudic review.

The very lack of repentance (although he wanted it?) From the point of view of clinical psychodiagnostics can be explained as psychopathy, de facto lack of empathy, more precisely people with a positive history of psychopathy have the form of prospective repentance, but not retrospective what hypothetical words for Esau (Soderstrom 2003), Skelly, and Kiehl 2013) (Domes et al. 2013). We also note that he was a hunter from an early age, leading us to conclude that he may have, conditionally speaking, harmed animals, (most psychopaths who commit murder or a series of murders have a history of hostility to animals at an early age) (Allely et al. (2014) (Miller 2014) The neurobiology of the brain is responsible for a given behavior, which, in this case, dictates the classification of personality. (Jalava, Griffiths, and Maraun 2015)

\section{Is / Why is Esau a psychopath? Neuroscience}

The etiology of the word psychopathy finds a place in the Greek original where $\psi v \chi \eta ́$ denotes the soul, and $\pi \alpha \dot{\theta} \theta$ o $\zeta$ in this case suffering. Psychopathy itself is explained by interpersonal and emotional abnormalities, manipulativeness, lack, and absence of empathy and guilt, and there is also antisocial behavior and aggression that is recurrent (Hare and Neumann 2009). Psychopathy is associated with brain abnormalities especially in the orbital frontal (ofPFC) and anterior/medial temporal regions, which are responsible for cognitive-behavioral and emotional regulation of behavior (Ly et al. 2012). Psychopaths brains process differently and have impartiality of responsiveness to affective information, that is, they have selective attention, which can be considered cognitive defects (Ribeiro da Silva, Rio, and Salekin 2015).

Structural brain findings support these patterns of abnormalities observed in hippocampal volume, cortical thickness, amygdala (fear, aggression), prefrontal cortex, 
dorsomedial prefrontal cortical region, where decreased activity is significantly associated with social cognition, including empathy, morality, and theory of mind), insula, temporal lobes, striatum, and anterior cingulate. Thus, here we have a certain dysfunction in cortical gyrification in the wider paralimbic network (Konicar et al. 2015), which has its key role in psychopathy and a positive anamnesis of the same. It should be pointed out that only damage to the orbit of the frontal cortex and ventromedial regions results in pseudopsychopathic behavior so that the neurobiology of the brain and its damage dictate the behavior (Müller et al. 2008).

Psychopaths are born with a brain that has a certain dysfunction, which we mentioned earlier, because neurogenesis and synaptogenesis itself testify to that, but also genetic predisposition is the basis of psychopathic personality structure (Monoamine Oxidase MAO-A gene-aggressive behavior) (Sadeh, Javdani, and Verona 2013)4.

\section{Conclusion}

Is Esau really a psychopath? Judging by the Christian and Jewish traditions and the information available to those two traditions, we can at least conditionally reconstruct the psychology of the personality of Esau, Isaac's son, and give neurobiological guidelines for his behavior. What is more striking in the Christian tradition is precisely his unrepentance, in fact the absence of empathy and retrospective repentance, which can place him among people who possess a psychopathic personality structure. The question is whether his ontology is really like that, and it remains to be seen in some philosophical and theological discourse, because this research is limited only to the neuroaspect of a given subject, so this work, on the other hand, has shortcomings. According to Jewish tradition, Esau was later killed by the descendants of Jacob, so to some extent he is also a tragic character. 


\section{References}

Ackroyd P, Exile and Restoration: A Study in Hebrew Thought of the Sixth Century B.C., 1968, p. 224.

Anderson, Bradford A. (2011). Brotherhood and Inheritance: A Canonical

Reading of the Esau and Edom Traditions. T\&T Clark International. p. 35. ISBN 9780567368256.

Allely, Clare S., Helen Minnis, Lucy Thompson, Philip Wilson, and Christopher Gillberg. 2014. "Neurodevelopmental and Psychosocial Risk Factors in Serial Killers and Mass Murderers." Aggression and Violent Behavior. https://doi.org/10.1016/j.avb.2014.04.004.

Babylonian Talmud, Volume - Bava Basra (PDF). halakhah.com. p. 16b (Soncino English translation).

Bereshit Rabbah 63:6
Даничић Ђ, Караџић В, са исправкама и преводима Светог Владике Николаја, 2007 "Библија" Глас Цркве.

Decety, Jean, Laurie R. Skelly, and Kent A. Kiehl. 2013. "Brain Response to Empathy-Eliciting Scenarios Involving Pain in Incarcerated Individuals with Psychopathy." JAMA Psychiatry. https://doi.org/10.1001/jamapsychiatry.2013.27.

Domes, Gregor, Pia Hollerbach, Knut Vohs, Andreas Mokros, and Elmar Habermeyer. 2013. "Emotional Empathy and Psychopathy in Offenders: An Experimental Study." Journal of Personality Disorders. https://doi.org/10.1112/S0025579300010226.

Eisenberg, Dan T A, Benjamin Campbell, James MacKillop, J. Koji Lum, and David S. Wilson. 2007. "Season of Birth and Dopamine Receptor Gene Associations with Impulsivity, Sensation Seeking and Reproductive Behaviors." PLoS ONE. https://doi.org/10.1371/journal.pone.0001216.

Fonagy, Peter, Howard Steele, and Miriam Steele. 1991. "Maternal Representations of Attachment during 
Pregnancy Predict the Organization of Infant-Mother Attachment at One Year of Age." Child Development. https://doi.org/10.1111/j.1467-8624.1991.tb01578.x.

Han, Jiali, Peter Kraft, Graham A. Colditz, Jason Wong, and David J. Hunter. 2006. "Melanocortin 1 Receptor Variants and Skin Cancer Risk." International Journal of Cancer. https://doi.org/10.1002/ijc.22074.

Hare, Robert D., and Craig S. Neumann. 2009. "Psychopathy: Assessment and Forensic Implications." Canadian Journal of Psychiatry. https://doi.org/10.1177/070674370905401202.

Hicks, Brian M., Marie D. Carlson, Daniel M. Blonigen, Christopher J. Patrick, William G. Iacono, and Matt Mgue. 2012. "Psychopathic Personality Traits and Environmental Contexts: Differential Correlates, Gender Differences, and Genetic Mediation." Personality Disorders: Theory, Research, and Treatment. https://doi.org/10.1037/a0025084.

Hofer, Myron A. 2006. "Psychobiological Roots of Early Attachment." Current Directions in Psychological
Science.

https://doi.org/10.1111/j.0963-

7214.2006.00412.x.

Jalava, J, S Griffiths, and M Maraun. 2015. The Myth of the Born Criminal: Psychopathy, Neurobiology, and the Creation of the Modern Degenerate. The Myth of the Born Criminal: Psychopathy, Neurobiology, and the Creation of the Modern Degenerate.

Johnson, Sara B., Robert W. Blum, and Jay N. Giedd. 2009. "Adolescent Maturity and the Brain: The Promise and Pitfalls of Neuroscience Research in Adolescent Health Policy." Journal of Adolescent Health. https://doi.org/10.1016/j.jadohealth.2009.05.016.

Konicar, Lilian, Ralf Veit, Hedwig Eisenbarth, Beatrix Barth, Paolo Tonin, Ute Strehl, and Niels Birbaumer. 2015. "Brain Self-Regulation in Criminal Psychopaths." Scientific Reports. https://doi.org/10.1038/srep09426.

Lalueza-Fox, Carles, Holger Römpler, David Caramelli, Claudia Stäubert, Giulio Catalano, David Hughes, Nadin Rohland, et al. 2007. "A Melanocortin 1 Receptor Allele Suggests Varying Pigmentation among Neanderthals." Science. https://doi.org/10.1126/science.1147417. 
Ly, Martina, Julian C. Motzkin, Carissa L. Philippi, Gregory R. Kirk, Joseph P. Newman, Kent A. Kiehl, and Michael Koenigs. 2012. "Cortical Thinning in Psychopathy." American Journal of Psychiatry. https://doi.org/10.1176/appi.ajp.2012.11111627.

Miller, Laurence. 2014. "Serial Killers: I. Subtypes, Patterns, and Motives." Aggression and Violent Behavior. https://doi.org/10.1016/j.avb.2013.11.002.

Müller, Jürgen L., Susanne Gänßbauer, Monika Sommer, Katrin Döhnel, Tatjana Weber, Tobias Schmidt-Wilcke, and Göran Hajak. 2008. "Gray Matter Changes in Right Superior Temporal Gyrus in Criminal Psychopaths. Evidence from Voxel-Based Morphometry." Psychiatry Research - Neuroimaging. https://doi.org/10.1016/j.pscychresns.2007.08.010.

Ribeiro da Silva, Diana, Daniel Rijo, and Randall T. Salekin. 2015. "The Evolutionary Roots of Psychopathy." Aggression and Violent Behavior. https://doi.org/10.1016/j.avb.2015.01.006.

Sadeh, Naomi, Shabnam Javdani, and Edelyn Verona. 2013. "Analysis of Monoaminergic Genes, Childhood
Abuse, and Dimensions of Psychopathy." Journal of Abnormal Psychology. https://doi.org/10.1037/a0029866.

Soderstrom, Henrik. 2003. "Psychopathy as a Disorder of Empathy." European Child and Adolescent Psychiatry. https://doi.org/10.1007/s00787-003-0338-y.

Zuckerman, Marvin, and D. Michael Kuhlman. 2000. "Personality and Risk-Taking: Common Biosocial Factors." Journal of Personality. https://doi.org/10.1111/1467-6494.00124. 